JMI Vol. 42 No. 2, Desember 2020

METAL INDONESIA

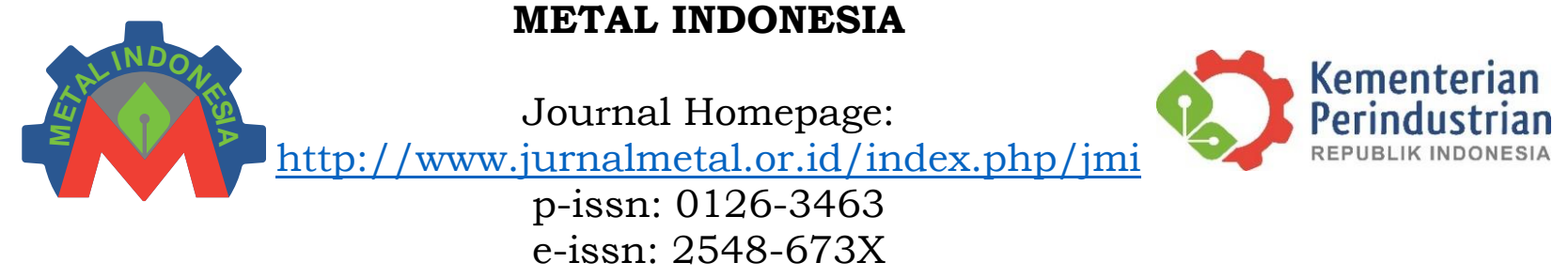

\title{
KAJIAN LITERATUR PARAMETER PROSES REDUKSI SELEKTIF BIJIH NIKEL LATERIT
}

\section{LITERATURE REVIEW OF PARAMETER IN SELECTIVE REDUCTION PROCESS OF LATERITIC NICKEL ORE}

\author{
Fajar Nurjaman $^{1,2}$, Fathan Bahfie ${ }^{2}$, Ulin Herlina ${ }^{2}$, Widi Astuti², dan Bambang Suharno ${ }^{1}$ \\ ${ }^{1}$ Departemen Teknik Metalurgi dan Material, Universitas Indonesia, Depok, Indonesia \\ ${ }^{2}$ Balai Penelitian Teknologi Mineral, Lembaga Ilmu Pengetahuan Indonesia, Lampung, Indonesia \\ E-mail : suharno@metal.ui.ac.id
}

\begin{abstract}
Abstrak
Proses reduksi selektif bijih nikel laterit merupakan salah satu metode pirometalurgi yang dilakukan dengan mereduksi senyawa besi dan nikel oksida dalam bijih nikel laterit pada temperatur $1100-1200^{\circ} \mathrm{C}$ menjadi logam ferronikel dengan membatasi metalisasi besi melalui penambahan aditif dan penggunaan jumlah reduktan yang terbatas. Kandungan dan perolehan nikel dalam konsentrat semakin meningkat dengan semakin banyaknya aditif yang ditambahkan. Namun penambahan aditif dalam jumlah banyak akan meningkatkan biaya produksi proses reduksi selektif tersebut. Penggunaan reduktan batubara dengan kandungan sulfur tinggi memungkinkan untuk mensubstitusi penggunaan aditif. Proses reduksi selektif tidak hanya melibatkan reaksi solid-state melainkan juga melibatkan reaksi solid-liquid state. Oleh karena itu biaya produksi proses reduksi selektif juga dapat diminimalkan melalui penggunaan basisitas yang optimal sehingga diperoleh kondisi proses dengan titik lebur fasa metalik dan non-metalik yang rendah. Dengan konsumsi energi/temperatur reduksi yang lebih rendah, diharapkan teknologi reduksi selektif bijih nikel laterit mampu menggantikan teknologi pirometalurgi konvensional (blast furnace dan rotary kiln electric arc furnace). Teknologi ini juga diharapkan mampu menjadi solusi permasalahan terkait pengolahan bijih nikel laterit kadar rendah $(<1,7 \% \mathrm{Ni})$ yang ketersediaannya sangat berlimpah di dunia, dimana nilai keekonomisan yang diperoleh akan sangat rendah jika menggunakan teknologi pirometalurgi konvensional.
\end{abstract}

Kata Kunci: bijih nikel laterit, ferronikel, aditif, reduktan, basisitas

\begin{abstract}
Selective reduction for nickel laterite ore is one of a pyrometallurgical process carried out to reduce iron and nickel oxide in lateritic nickel ore into ferronickel by retarding the metallization of iron with the addition of additives and limited use of reductant. Nickel grade and recovery will increase with the more addition of additives. Nevertheless, the addition of additives in a large amount will enhance the cost production of this selective reduction process. The use of high sulfur-bearing coal allows substituting the use of additives. The selective reduction process does not only involve solid-state reaction but also solidliquidus state reaction. Therefore, the cost production of this selective reduction process also can be reduced by modifying the basicity to obtain the low melting temperature of non-metallic phase. The selective
\end{abstract}


reduction for lateritic nickel ore processing, which has a low energy consumption/low-temperature process, is expected could substitute the pyrometallurgy conventional route (blast furnace dan rotary kiln electric arc furnace) for nickel ore processing. It is also expected to solve the utilization of low-grade lateritic nickel ore $(<1,7 \% \mathrm{Ni})$, a very large reserves in the world, where it will uneconomically if processed by those conventional pyrometallurgy methods.

Keywords : lateritic nickel ore, ferronickel, additives, reductant, basicity

\section{PENDAHULUAN \\ BIJIH NIKEL LATERIT DAN TEKNOLOGI PENGOLAHANNYA}

Logam nikel merupakan salah satu logam sangat penting yang banyak digunakan untuk aplikasi infrastruktur, konstruksi, transportasi dan mesin industri. Logam nikel umumnya digunakan dalam bentuk paduan logam, seperti stainless steel, super alloys dan baja berkekuatan tinggi.

Kebutuhan logam nikel akan terus meningkat, hingga mencapai $140-175 \%$ pada Tahun 2025 (Elskaki et al., 2017). Sebanyak 75\% bijih nikel tersedia di alam dalam bentuk senyawa oksida (laterit), sedangkan sisanya dalam bentuk sulfida. Namun saat ini, penggunaan bijih nikel sulfida (58\%) dalam industri pengolahan nikel jauh lebih banyak dibandingkan bijih nikel laterit (42\%) (Dalvi et al., 2004). Proses benefisiasi/pemurnian bijih nikel laterit (limonit dan saprolit) secara fisik, menggunakan metode gravity separation dan magnetic separation sangat sulit dilakukan (Farrokhpay et al., 2019; Warner et al., 2006). Hal tersebut dikarenakan unsur nikel dan besi berikatan dengan senyawa kompleks hidroksida yaitu berupa lizardite, serpentine $(\mathrm{Mg}, \mathrm{Fe}, \mathrm{Ni})_{3} \mathrm{Si}_{2} \mathrm{O}_{5}(\mathrm{OH})_{4}$ dan goethite $(\mathrm{FeOOH})$. Oleh karena itu pada umumnya teknologi yang saat ini digunakan untuk memisahkan logam besi dan nikel dari pengotornya adalah melalui proses smelting/peleburan (pirometalurgi) dan proses pelindian/leaching dalam kondisi asam (hidrometalurgi) (Wills dan Mun, 2006; Astuti et al., 2016). Menurut Oxley dan Barcza (2013) bahwa saat ini sebanyak $80 \%$ pengolahan bijih nikel laterit menjadi Nickel Pig Iron (NPI) dan ferronikel (FeNi) umumnya mengunakan teknologi pirometalurgi (Blast Furnace, Submerged Arc Furnace, Rotary Kiln Electric Arc Furnace), dikarenakan teknologi tersebut sudah terbukti (well-proven) pada skala industri (Rao et al., 2013). Namun tingginya biaya investasi dan konsumsi energi akibat penggunaan temperatur proses yang tinggi $\left(1200-1500^{\circ} \mathrm{C}\right)$ menjadi salah satu pertimbangan dalam pemilihan teknologi tersebut (Chukwuleke et al., 2009).

Proses hidrometalurgi umumnya dilakukan untuk pengolahan bijih nikel laterit dengan kandungan kurang dari 1,5\% Ni. Menurut Oxley dan Barcza et al. (2013), metode hidrometalurgi, salah satunya adalah High Pressure Acid Leach (HPAL) dinyatakan tidak ekonomis dan membutuhkan biaya investasi yang besar, selain itu teknologi tersebut belum banyak terbukti (unwell proven) pada skala indusri. Oleh karena itu, perlu dikembangkan suatu teknologi pengolahan bijih nikel laterit kadar rendah dengan biaya produksi dan investasi yang murah.

\section{TEKNOLOGI REDUKSI SELEKTIF BIJIH NIKEL LATERIT}

Teknologi proses reduksi selektif (parsial) dikembangkan untuk mengolah bijih nikel laterit menjadi konsentrat logam ferronikel. Teknologi tersebut merupakan gabungan dari metode pirometalurgi dan benefisiasi secara fisik, dimana bijih nikel laterit terlebih dahulu direduksi pada temperatur tertentu yang kemudian dilanjutkan dengan proses pemisahan magnetik untuk memisahkan pengotor/slag (non-magnetik) dengan konsentrat ferronikel (magnetik). Proses reduksi dilakukan pada temperatur proses yang rendah (1100-1200 ${ }^{\circ} \mathrm{C}$ ) dengan penambahan material/gas reduktan dan sejumlah aditif (senyawa sulfat, karbonat atau khlorida) pada bijih nikel laterit.

Proses reduksi selektif ditujukan untuk mereduksi keseluruhan senyawa oksida nikel, namun hanya mereduksi sebagian senyawa oksida besi yang terkandung dalam bijih nikel laterit. Proses reduksi diawali dengan menghilangkan senyawa hidroksida, yaitu serpentine$(\mathrm{Mg}, \mathrm{Fe}, \mathrm{Ni})_{3} \mathrm{Si}_{2} \mathrm{O}_{5}(\mathrm{OH})_{4}$ dan goethite- $(\mathrm{FeOOH})$. Pada temperatur $500-600^{\circ} \mathrm{C}$, Serpentine akan berubah menjadi forsterite- $(\mathrm{Mg}, \mathrm{Fe}, \mathrm{Ni}) \mathrm{SiO}_{3}$ dan enstatite- $\left(\mathrm{Mg}, \mathrm{Fe}, \mathrm{Ni}_{2} \mathrm{SiO}_{4}\right.$, sedangkan goethite akan berubah menjadi hematite- $\left(\mathrm{Fe}_{2} \mathrm{O}_{3}\right)$. 
Pemanasan lebih lanjut akan menyebabkan nikel dalam forsterite dan enstatite berubah menjadi nikel oksida (NiO) dan logam nikel-Ni, sedangkan hematite akan berubah menjadi magnetite $-\mathrm{Fe}_{3} \mathrm{O}_{4}$, wustite-FeO, dan logam besi-Fe. Berikut di bawah ini adalah persamaan (1-8) menunjukkan reaksi yang terbentuk dalam proses reduksi bijih nikel laterit: (Harris et al., 2009; Valix dan Cheung, 2002; Solihin, 2015)

$(\mathrm{Mg}, \mathrm{Fe}, \mathrm{Ni})_{3} \mathrm{Si}_{2} \mathrm{O}_{5}(\mathrm{OH})_{4} \rightarrow$ $(\mathrm{Mg}, \mathrm{Fe}, \mathrm{Ni}) \mathrm{SiO}_{3}+(\mathrm{Mg}, \mathrm{Fe}, \mathrm{Ni})_{2} \mathrm{SiO}_{4}+2 \mathrm{H}_{2} \mathrm{O}$

$$
\begin{aligned}
& 2 \mathrm{FeOOH} \rightarrow \mathrm{Fe}_{2} \mathrm{O}_{3}+\mathrm{H}_{2} \mathrm{O} \\
& 3 \mathrm{Fe}_{2} \mathrm{O}_{3}+\mathrm{CO} \rightarrow 2 \mathrm{Fe}_{3} \mathrm{O}_{4}+\mathrm{CO}_{2} \\
& \mathrm{Fe}_{3} \mathrm{O}_{4}+\mathrm{CO} \rightarrow 3 \mathrm{FeO}+\mathrm{CO}_{2} \\
& \mathrm{FeO}+\mathrm{CO} \rightarrow \mathrm{Fe}+\mathrm{CO}_{2} \\
& \mathrm{NiO}+\mathrm{CO} \rightarrow \mathrm{Ni}+\mathrm{CO}_{2} \\
& \mathrm{Fe}+\mathrm{Ni} \rightarrow \mathrm{FeNi} \\
& \mathrm{C}+\mathrm{CO}_{2} \rightarrow 2 \mathrm{CO}
\end{aligned}
$$

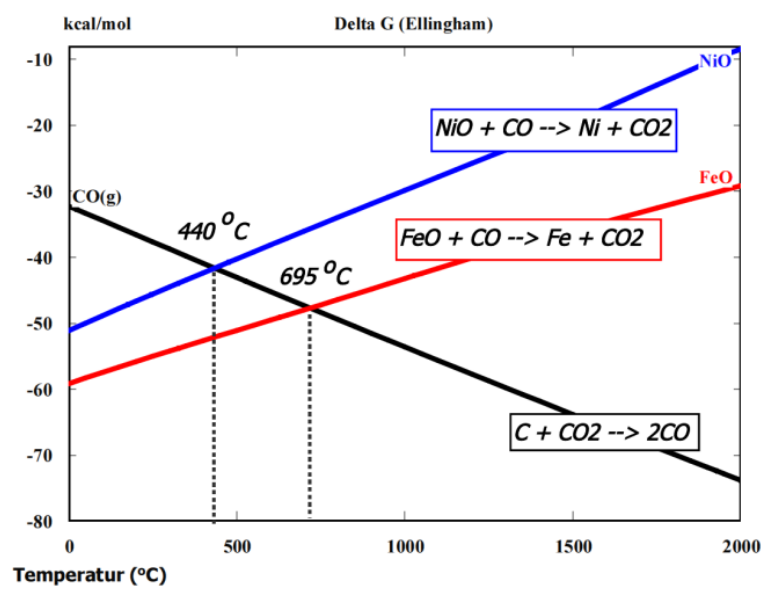

Gambar 1. Potongan diagram Ellingham antara nikel oksida $(\mathrm{NiO})$, besi oksida $(\mathrm{FeO})$ dan gas karbon monooksida (CO) (Maksum et al., 2018).

Dari diagram pada Gambar 1 terlihat bahwa temperatur terendah agar reduksi $\mathrm{NiO}$ oleh karbon terjadi adalah $440^{\circ} \mathrm{C}$ pada tekanan 1 atm (Maksum et al., 2018). Nilai energi bebas Gibbs pada reaksi pembentukan $\mathrm{NiO}$ bernilai lebih tinggi daripada nilai energi bebas Gibbs pada reaksi pembentukan gas $\mathrm{CO}_{2}$, sehingga reduksi $\mathrm{NiO}$ dapat mudah terjadi ketika bereaksi dengan gas CO. Sedangkan temperatur terendah untuk reduksi $\mathrm{FeO}$ adalah $695^{\circ} \mathrm{C}$ (Rao et al., 2016). Perbedaan temperatur reduksi tersebut memungkinkan untuk melakukan pembatasan reduksi besi oksida terhadap nikel oksida.
Meskipun reduksi besi cukup penting, dimana besi metalik berasosiasi dengan nikel membentuk ferronikel yang selanjutnya dipisahkan melalui proses separasi magnetik. Namun metalisasi besi harus dibatasi karena dapat mengurangi kandungan nikel dalam hasil perolehan ferronikel (Rao et al. 2016).

\section{STATE OF THE ART (KONDISI PENELITIAN TERKINI) Pengaruh Aditif Sulfur/Sulfat Dalam Proses Reduksi Selektif}

Beberapa penelitian terkait penggunaan aditif dalam proses reduksi selektif untuk meningkatkan keefektifan dan efisiensi dari proses reduksi selektif, diantaranya meningkatkan kadar dan perolehan nikel dalam konsentrat (Bunjaku et al., 2011). Salah satu unsur yang dapat digunakan sebagai aditif adalah sulfur (Jiang et al. 2013; Elliot et al., 2017; Harris et al., 2011; Elliot et al., 2015; Harris et al., 2013). Penelitian lain juga telah dilakukan dengan menggunakan senyawa sulfur sebagai aditif, seperti pyrite-Fe2S (Harris et al., 2013); sodium sulfat- $\mathrm{Na}_{2} \mathrm{SO}_{4}$ (Li et al., 2012; Jiang et al. 2013; Chen et al., 2016; Rao et al., 2016); sodium sulfida- $\mathrm{Na}_{2} \mathrm{~S}$ (Jiang et al., 2013); dan kalsium sulfat-CaSO${ }_{4}$ (Zhu et al., 2012; Setiawan et al., 2014), menemukan bahwa penambahan senyawa sulfur dapat meningkatkan kadar dan perolehan nikel pada hasil akhir separasi magnetik (Zhu et al., 2012; Jiang et al., 2013). Hal tersebut dikarenakan penambahan aditif sulfat mampu meningkatkan ukuran butir ferronikel (warna putih) sehingga akan meningkatkan derajat liberasi ferronikel dari pengotor, sebagaimana ditunjukkan dalam Gambar 2 (Hang et al., 2020). Menurut Shofi et al. (2019) penggunaan aditif sulfat memberikan hasil yang lebih baik dibandingkan aditif karbonat dan khlorida pada jumlah penambahan yang sama. Dari penelitian sebelumnya diperoleh bahwa aditif sodium sulfat memberikan kadar dan perolehan nikel yang jauh lebih baik dibandingkan dengan sodium karbonat (Nurjaman, 2019). Penambahan dosis sodium sulfat dapat menurunkan metalisasi Fe melalui mekanisme reaksi sulfidasi dengan pembentukan senyawa troilite-FeS, sebagaimana ditunjukkan persamaan (9-13). (Rao et al., 2016). 


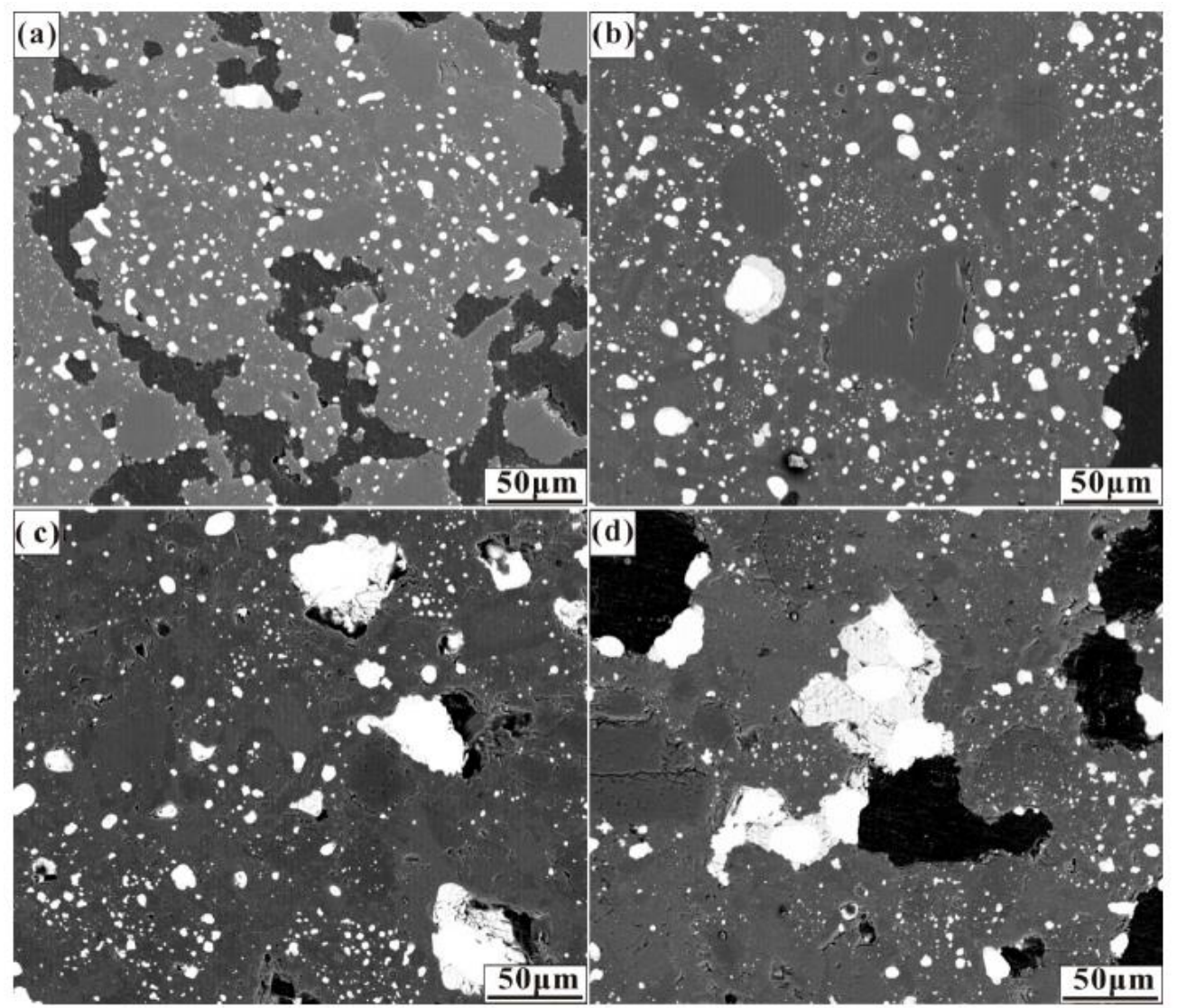

Gambar 2. Pengaruh penambahan aditif kalsium sulfat dalam proses reduksi bijih nikel laterit pada temperatur $1200^{\circ} \mathrm{C}$ : (a) $4 \%$, (b) $8 \%$, (c) $12 \%$, (d) $16 \%$ (Hang et al., 2020)

$\mathrm{Na}_{2} \mathrm{SO}_{4}+4 \mathrm{CO} \rightarrow \mathrm{Na}_{2} \mathrm{~S}+4 \mathrm{CO}_{2}$

$\mathrm{Na}_{2} \mathrm{~S}+\mathrm{FeO}+\mathrm{SiO}_{2} \rightarrow \mathrm{Na}_{2} \mathrm{SiO}_{3}+\mathrm{FeS}$

$\mathrm{NaS}+\mathrm{NiO}+\mathrm{SiO}_{2} \rightarrow \mathrm{Na}_{2} \mathrm{SiO}_{3}+\mathrm{NiS}$

$\mathrm{NiS}+\mathrm{FeO}+\mathrm{CO} \rightarrow \mathrm{FeS}+\mathrm{Ni}+\mathrm{CO}_{2}$

$\mathrm{Na}_{2} \mathrm{SO}_{4}+\mathrm{SiO}_{2}+\mathrm{CO} \rightarrow \mathrm{Na}_{2} \mathrm{SiO}_{3}+\mathrm{SO}_{2}+$

$\mathrm{CO}_{2}$

FeS dengan titik lebur rendah $\left(980^{\circ} \mathrm{C}\right)$ akan membentuk fasa liquid/cair yang berperan sebagai agen aktivasi untuk meningkatkan laju transfer massa ion-ion logam selama proses reduksi, sehingga partikel ferronikel mengalami agregasi dan terbungkus oleh FeS (Li et al., 2012). Selain itu, sodium (Na) dalam sodium sulfat akan bereaksi dengan senyawa silikon dan alumunium oksida membentuk senyawa nepheline $-\mathrm{Na}_{2} \mathrm{SiO}_{3}$ yang bersifat non-magnetik (persamaan 11), mencegah terbentuknya senyawa fayalite $\left(\mathrm{Fe}_{2} \mathrm{SiO}_{4}\right)$ yang bersifat paramagnetik, sehingga akan memudahkan proses pemisahan magnetik untuk memisahkan pengotor dengan ferronikel.
Dari hasil penelitian yang dilakukan oleh Jiang et al. (2013) bahwa penggunaan aditif $\mathrm{Na}_{2} \mathrm{~S}$ mampu menghasilkan kandungan nikel yang lebih baik, akan tetapi perolehan nikelnya lebih rendah $(<90 \%)$ dibandingkan sodium sulfat. Beberapa penelitian mengemukakan bahwa penambahan dosis sodium sulfat dapat menurunkan metalisasi Fe. Hal ini dibuktikan dengan meningkatnya energi aktivasi dari $75,97 \mathrm{~kJ} / \mathrm{mol}$ menjadi 98,53 $\mathrm{kJ} / \mathrm{mol}$ akibat adanya penambahan aditif sodium sulfat (Rao et al., 2016).

\section{Pengaruh Reduktan Dalam Reduksi Selektif Bijih Nikel Laterit}

Material/gas reduktan digunakan untuk mereduksi besi dan nikel oksida menjadi logam ferronikel. Menurut Pan et al. (2013), selain melalui penggunaan aditif, proses reduksi selektif juga dapat dilakukan dengan membatasi jumlah besi tereduksi melalui pembatasan jumlah reduktan, dimana dari hasil penelitian yang telah dilakukan menunjukkan bahwa kandungan nikel 
akan semakin berkurang dengan meningkatnya jumlah reduktan

Selain sebagai aditif, keberadaan sulfur mampu menjadi agen reduktor dalam proses reduksi bijih nikel laterit melalui persamaan (14). Namun laju difusi sulfur yang keluar dari bijih nikel laterit dalam proses reduksi jauh lebih cepat dibandingkan dengan persamaan (14), sehingga hanya sebagian kecil dari sulfur yang dapat berperan sebagai reduktor. Penambahan reduktor padat, seperti batubara yang mampu menghasilkan gas reduktor (CO) memiliki laju reaksi reduksi (persamaan (16)) yang lebih cepat dibandingkan dengan persamaan (14).

$$
\begin{aligned}
& \mathrm{Fe}_{2} \mathrm{O}_{3}+\frac{3}{4} \mathrm{~S}_{2}=2 \mathrm{Fe}+\frac{3}{2} \mathrm{SO}_{2} \\
& \mathrm{Fe}+\mathrm{S}_{2}=\mathrm{FeS}_{2} \\
& \mathrm{Fe}_{2} \mathrm{O}_{3}+3 \mathrm{CO}=2 \mathrm{Fe}+3 \mathrm{CO}_{2}
\end{aligned}
$$

Penelitian terkait penambahan reduktan batubara pada proses reduksi bijih nikel laterit jenis limonit telah dilakukan (Elliot et al., 2017). Penambahan reduktan akan menghasilkan lebih banyak gas reduktan (CO) sehingga akan meningkatkan suasana reduksi yang berdampak pada semakin banyaknya logam (besi dan nikel) oksida yang tereduksi. Ukuran partikel bijih nikel laterit semakin meningkat seiring dengan bertambahnya reduktor. Namun, peningkatan metalisasi besi mengakibatkan rendahnya kadar nikel dalam konsentrat yang diperoleh.

Penggunaan batubara (bituminous dan lignite) sebagai reduktor telah banyak dilakukan (Elliot et al., 2017; Elliot et al., 2015; Jiang et al., 2013; Li et al., 2012), dikarenakan ketersediaan yang cukup melimpah dan harganya yang relatif jauh lebih murah. Berdasarkan penelitian yang telah dilakukan oleh Harjanto et al. (2019), bahwa penggunaan reduktan batubara lignite (low-rank coal) tidak mempengaruhi kandungan dan perolehan nikel, namun mempengaruhi perolehan logam, dimana perolehan logam pada proses reduksi dengan menggunakan reduktan batubara lignite jauh lebih rendah dibandingkan dengan batubara bituminous. Hal tersebut dikarenakan kandungan karbon dalam batubara lignite yang lebih rendah dibandingkan dengan bituminous.

Penggunaan reduktan berbasis biomassa juga mulai banyak digunakan dalam proses reduksi selektif bijih nikel laterit dikarenakan karakteristiknya yang ramah lingkungan, dimana reduktan biomassa memiliki kandungan sulfur yang lebih rendah dibandingkan dengan batubara, sehingga mampu meminimalisir pembentukan gas $\mathrm{SO}_{2}$ yang berdampak negatif terhadap lingkungan (Petrus et al., 2019; Suharno et al., 2019).

\section{Pengaruh Basisitas Terhadap Proses Reduksi Bijih Nikel Laterit}

Basisitas sangat berpengaruh dalam proses peleburan, dimana temperatur lebur slag/pengotor yang rendah akan memberikan dampak positif, dikarenakan laju reaksi difusi akan berlangsung lebih cepat dalam kondisi cair/liquidus. Basisitas dinyatakan sebagai rasio antara senyawa pengotor bersifat asam dan basa, yang umumnya dituliskan oleh persamaan (17-19).

$$
\begin{aligned}
& B_{\text {biner }}=\frac{\mathrm{MgO}}{\mathrm{SiO}_{2}} \text { atau } \frac{\mathrm{CaO}}{\mathrm{SiO}_{2}} \\
& B_{\text {ternier }}=\frac{\mathrm{CaO}+\mathrm{MgO}}{\mathrm{SiO}_{2}} \text { atau } \frac{\mathrm{CaO}}{\mathrm{SiO}_{2}+\mathrm{Al}_{2} \mathrm{O}_{3}} \\
& B_{\text {quarterner }}=\frac{\mathrm{CaO}+\mathrm{MgO}}{\mathrm{Al}_{2} \mathrm{O}_{3}+\mathrm{SiO}_{2}}
\end{aligned}
$$

Pengaruh basisitas terhadap proses peleburan bijih nikel laterit pada temperatur $1550^{\circ} \mathrm{C}$ telah dilakukan oleh Zhu et al. (2016), dimana nilai basisitas biner $\left(\mathrm{CaO} / \mathrm{SiO}_{2}\right)$ optimal adalah 1,0 dengan diperolehnya senyawa dalam slag berupa melilite (2CaO. $\mathrm{MgO} .2 \mathrm{SiO}_{2}$ ).

Pengaruh basisitas biner dalam proses reduksi selektif nikel oksida belum banyak dipelajari. Pan et al. (2013) mempelajari pengaruh basisitas biner $\left(\mathrm{CaO} / \mathrm{SiO}_{2}\right)$ terhadap kandungan nikel oksida dalam slag hasil peleburan nikel, dimana kandungan nikel dalam produk akan berkurang dengan semakin meningkatnya basisitas akibat semakin tingginya temperatur (titik) lebur. Kandungan dan perolehan nikel optimum diperoleh pada basisitas 0,15 . Harjanto dan Ulum (2015) juga mempelajari pengaruh basisitas biner $\left(\mathrm{SiO}_{2} / \mathrm{MgO}\right)$ dalam proses reduksi senyawa nikel oksida ( $\mathrm{NiO})$, dimana perolehan nikel meningkat seiring dengan penambahan $\mathrm{SiO}_{2}$ atau dengan kata lain semakin rendah basisitas (kondisi asam) maka perolehan nikel akan semakin meningkat. Tian et al. (2020) telah melakukan penelitian terkait pengaruh basisitas $\mathrm{CaO} / \mathrm{SiO}_{2}$ dengan nilai $0,01-0,30$ melalui 
modifikasi penambahan $\mathrm{CaCO}_{3}$ terhadap proses reduksi selektif bijih nikel laterit jenis saprolit kadar rendah $(1,29 \mathrm{Ni}$ dan $16,31 \mathrm{Fe})$, dimana kadar dan perolehan logam meningkat seiring dengan meningkatnya basisitas. Hal tersebut dikarenakan $\mathrm{CaO}$ mampu merusak ikatan silikat sehingga membebaskan senyawa Fe dan Ni yang terperangkap didalamnya, dimana kemudian $\mathrm{CaO}$ akan bereaksi dengan silikat membentuk senyawa $\mathrm{CaMg}\left(\mathrm{SiO}_{3}\right)_{2}$ dan $\mathrm{Ca}_{2} \mathrm{MgSi}_{2} \mathrm{O}_{7}$ yang memiliki titik lebur rendah, sehingga dengan terbentuknya fasa liquid tersebut akan mampu meningkatkan kadar nikel dalam konsentrat serta mampu mendorong pertumbuhan partikel ferronikel yang akan meningkatkan perolehan logam.

Proses pemecahan senyawa silikat ditunjukkan pada Gambar 3, dimana oksigen bebas pada senyawa oksida bersifat basa akan memecah senyawa silikat komplek $\left(\mathrm{Q}_{3}\right)$ menjadi senyawa yang lebih sederhana yaitu dimer $\left(\mathrm{Q}_{2}\right)$ dan monomer, dimana atom logam akan terbebas seiring dengan pecahnya senyawa kompleks silika tersebut (Shen et al., 2019).

Modifikasi basisitas biner melalui penambahan $\mathrm{SiO}_{2}$ dalam proses reduksi selektif bijih nikel laterit telah dipelajari oleh $\mathrm{Zhu}$ et al. (2019), dimana penambahan $\mathrm{SiO}_{2}$ mampu meningkatkan volume fasa liquid yang terbentuk, diantaranya fayalite- $2 \mathrm{FeO} \cdot \mathrm{SiO}_{2} \quad\left(1205 \quad{ }^{\circ} \mathrm{C}\right)$, senyawa $2 \mathrm{FeO} . \mathrm{SiO}_{2}-\mathrm{FeO}$ (titik lebur $1177^{\circ} \mathrm{C}$ ) dan senyawa $2 \mathrm{FeO} \cdot \mathrm{SiO}_{2}-\mathrm{SiO}_{2}$ (titik lebur $1178{ }^{\circ} \mathrm{C}$ ). Terbentuknya fasa liquidus akan berdampak positif terhadap laju mass transfer partikel logam, aglomerasi partikel ferronikel dan mengurangi laju difusi gas reduktan yang akan menghambat laju metalisasi besi. Selain itu terbentuknya fasa fayalite dengan reduksibilitas yang jauh lebih rendah dibandingkan wustite- $\mathrm{FeO}$ menjadi kunci selektifitas reduksi untuk memperkaya kandungan nikel dalam konsentrat ferronikel. Namun, menurut Harjanto dan Ulum (2015), penambahan $\mathrm{SiO}_{2}$ yang berlebih (hingga 20\%) akan berdampak negatif terhadap perolehan $\mathrm{Fe}$ dan juga $\mathrm{Ni}$, dimana keduanya akan berikatan membentuk senyawa Nickel-Iron-Magnesium-Silicate.

Umumnya basisitas biner digunakan dalam proses pengolahan/peleburan bijih besi. Penggunaan basisitas biner dalam pengolahan/peleburan bijih nikel laterit akan tidak tepat dikarenakan perbedaan kandungan senyawa non-logam dalam bijih nikel laterit yang berbeda dengan bijih besi (Li et al., 2015). Oleh karenanya perlu dilakukan suatu penelitian lebih lanjut terkait penggunaan model basisitas yang tepat, sebagaimana ditunjukkan dalam persamaan (1719).

\section{Penelitian Lebih Lanjut Tentang Proses Reduksi Selektif Bijih Nikel Laterit}

Penambahan aditif sulfur/sulfat dalam proses reduksi selektif bijih nikel laterit sangat berpengaruh terhadap peningkatan dan perolehan kadar nikel dalam konsentrat. Namun penggunaan aditif akan meningkatkan biaya produksi.

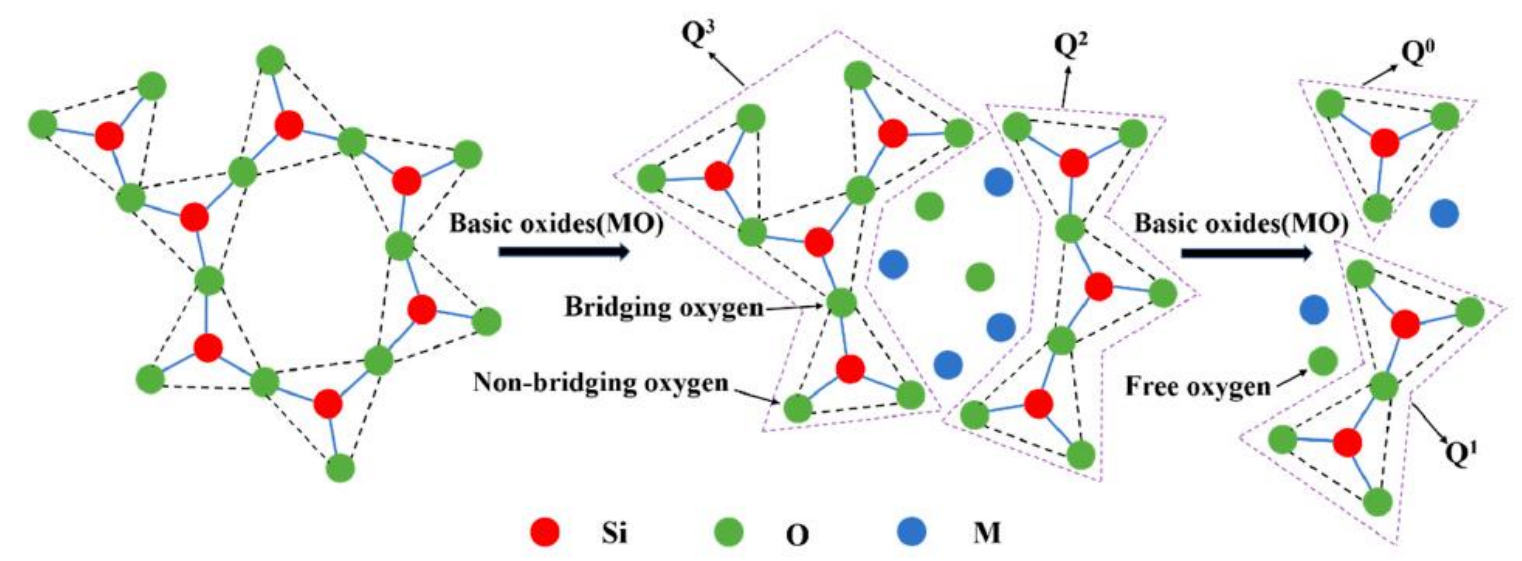

Gambar 3. Ilustrasi pecahnya senyawa silikat kompleks akibat penambahan senyawa oksida bersifat basa (Shen et al., 2019) 
Kandungan batubara dengan sulfur tinggi banyak ditemukan di Indonesia. Penggunaan batubara sebagai bahan bakar untuk pembangkit tenaga listrik dibatasi oleh kandungan sulfur kurang dari $1 \%$. Oleh karena itu, batubara dengan kandungan sulfur tinggi, belum termanfaatkan dengan baik. Kandungan sulfur dalam batubara berpotensi untuk mensubstitusi penggunaan aditif sulfur/sulfat. Hal tersebut didukung Elliot et al. (2017) yang menyatakan bahwa penambahan sulfur pada proses reduksi bijih nikel laterit mampu meningkatkan derajat metalisasi dari nikel dan besi. Setiawan et al. (2020) juga menyatakan bahwa penambahan sulfur akan menyebabkan partikel ferronikel mengalami aglomerasi sehingga meningkatkan ukuran butir partikel ferronikel dihasilkan yang berdampak terhadap peningkatan perolehan besi dan nikel. Namun keberadaan unsur pengotor lainnya dalam batubara, seperti posfor, perlu dipelajari pengaruhnya dalam proses reduksi selektif.

Basisitas sangat berpengaruh terhadap penentuan titik lebur dalam proses reduksi bijih nikel laterit, dimana proses tersebut tidak hanya melibatkan reaksi solid state transformation namun juga melibatkan solid-liquid state transformation akibat penambahan aditif sulfat dengan pembentukan senyawa troilite-FeS. Basisitas optimum dalam proses reduksi bijih nikel laterit diharapkan mampu meningkatkan kadar dan perolehan nikel pada temperatur reduksi yang lebih rendah, sehingga akan menurunkan biaya produksi serta menekan polusi yang ditimbulkan akibat penggunaan temperatur proses yang tinggi. Hingga saat ini belum banyak dipelajari pengaruh basisitas dalam proses reduksi selektif bijih nikel laterit. Penggunaan formula basisitas biner (Harjanto dan Ulum, 2015) dalam reduksi selektif akan tidak tepat dikarenakan perbedaan kandungan senyawa non-logam dalam bijih nikel laterit yang berbeda dengan bijih besi (Li et al., 2015), dimana dalam bijih nikel laterit terkandung senyawa $\mathrm{MgO}, \mathrm{Al}_{2} \mathrm{O}_{3}, \mathrm{SiO}_{2}$ dan sedikit $\mathrm{CaO}$. Oleh karena itu perlu dipelajari lebih lanjut terkait pengaruh basisitas quarterner $\left(\mathrm{CaO}+\mathrm{MgO} / \mathrm{SiO}_{2}+\mathrm{Al}_{2} \mathrm{O}_{3}\right)$ dalam proses reduksi selektif bijih nikel laterit.

Optimalisasi proses reduksi bijih nikel laterit ini diharapkan mampu menjawab permasalahan dunia terkait tingginya biaya produksi dalam pengolahan bijih nikel laterit menggunakan teknologi pirometalurgi konvensional (blast furnace dan rotary kiln electric arc furnace), dimana konsumsi energi pada proses reduksi selektif bijih nikel laterit jauh lebih rendah dikarenakan penggunaan temperatur proses reduksi yang rendah. Selain itu, tingginya konsumsi energi juga akan berdampak terhadap tingginya polusi yang dihasilkan.

Teknologi ini juga diharapkan mampu menjadi solusi untuk pemanfaatan bijih nikel laterit kadar rendah $(<1,7 \% \mathrm{Ni})$, dimana ketersediaannya sangat melimpah di dunia, khususnya di Indonesia. Pemanfaatannya menggunakan teknologi pirometalurgi konvensional menjadi tidak ekonomis dikarenakan membutuhkan konsumsi energi yang jauh lebih tinggi.

\section{KESIMPULAN}

Reduksi selektif merupakan salah satu teknologi dalam pengolahan bijih nikel laterit menjadi konsentrat logam ferronikel dengan menggunakan temperatur proses yang lebih rendah dibandingkan dengan teknologi peleburan konvensional (blast furnace dan rotary kiln electric arc furnace). Rendahnya perolehan nikel yang dihasilkan menjadi permasalahan dalam proses reduksi selektif. Upaya optimasi proses terus dilakukan melalui penggunaan berbagai jenis aditif dan reduktan. Pemilihan basisitas yang tepat dalam proses reduksi bijih nikel laterit diyakini dapat meningkatkan kadar dan perolehan nikel laterit dengan cara memperoleh kondisi reduksi pada temperatur lebur yang rendah.

\section{UCAPAN TERIMA KASIH}

Ucapan terima kasih ditujukan kepada Kementerian Riset dan Teknologi/Badan Riset dan Inovasi Nasional yang telah mendanai kegiatan ini melalui program Penelitian Disertasi Doktor (No: NKB-413 /UN.2RST/HKP.05.00.2020) dan Lembaga Ilmu Pengetahuan Indonesia melalui program Beasiswa By-Research.

\section{DAFTAR PUSTAKA}

Astuti, W., Hirajima, T., Sasaki, K., Okibe, N., 2016. Comparison of Atmospheric Citric Acid Leaching Kinetics of Nickel from Different Indonesian Saprolitic Ores. Hydrometallurgy 161, 138-151. 
Bunjaku, A., Kekkonen, M., Taskinen, P. \& Holappa, L., 2011. Thermal Behaviour of Hydrous Nickel-Magnesium Silicates When Heating Up To $750^{\circ} \mathrm{C}$. Mineral Processing and Extractive Metallurgy, vol. 120, No. 3,139-146.

Chukwuleke, O. P., Jiu-Ju, C., Chukwujekwu, S., Song, X., 2009. Shift from coke to coal using direct reduction method and challenges. Journal of Iron and Steel Research, 16(2): 01-05.

Chen, G-J., Shiau, J-S., Liu, S-H., and Hwang, WS., 2016. Optimal Combination of Calcination and Reduction Conditions as well as Na2SO4 Additive for Carbothermic Reduction of Limonite Ore. Materials Transaction, vol. 57, 1560-1566.

Dalvi, A.D., Bacon, W.G., Osborne, R.C., 2004. The past and future of nickel laterites. In: PDAC 2004 International Convention, March 7-10, 2004. pp. 1-27. $<$ http://www.pdac.ca/pdac/publications/papers/2 004/techprgm-dalvi-bacon.pdf>.

Elliot, R., Pickles, C. A., and Peacey, J., 2017. Ferronickel Particle Formation during The Carbothermic Reduction of a Limonitic Laterite Ore.Minerals Engineering, vol. 100, 166-176.

Elliot, R., Rodrigues, F., Pickles, C. A., and Peacey, J., 2015. A Two-stage Thermal Upgrading Process for Nickeliferous Limonitic Laterite Ores.Canadian Metallurgical Quarterly, vol. 100, 1-11.

Elskaki A., Reck, B. K., Graedel, T. E., 2017. Anthropogenic Nickel Supply, Demand, and Associated Energy and Water Use. Resources, Conversion \& Recycling, 125, 300-307.

Farrokhpay, S., Filippov, L., Fornasiero, D. 2019. Pre-concentration of nickel in laterite ores using physical separation methods. Minerals Engineering, 141: 105892.

Hang, G., Xue, Z., Wang, J., and Wu, Y. 2020. Mechanism of calcium sulphate on the aggregation and growth of ferronickel particles in the self-reduction of saprolitic nickel laterite ore. Metals, 10(423): 1-17. DOI: 10.3390 met10040423.

Harjanto, S. and Rhamdani, M. A. 2019. Sulfides formation in carbothermic reduction of saprolitic nickel laterite ore using low-rank coals and additives: a thermodynamic simulation analysis. Minerals, 9(631): 1-21. DOI: $10.3390 / \mathrm{min} 9100631$

Harjanto, S. and Ulum, R. M., 2015. $\mathrm{SiO}_{2} / \mathrm{MgO}$ Ratio Effect on Carbothermic Reaction of Synthetic Nickelliferrous Mixtures. Advanced Materials Research, 1112, 542545.

Harris, C. T., Peacey, J. G., and Pickles, C. A., 2009. Thermal Upgrading of Nickeliferous Laterite. Proceeding of 48th Conference Metallurgists, August 23-26, Ontario, Canada.

Harris, C. T., Peacey, J. G., and Pickles, C. A., 2011. Selective Sulphidation of a Nickeliferous Lateritic Ore.Minerals Engineering, vol. 24, 651-660.

Harris, C. T., Peacey, J. G., and Pickles, C. A., 2013. Selective Sulphidation and Flotation of Nickel from A Nickeliferous Laterite Ore. Minerals Engineering, vol. 54,21-31.

Jiang, M., Sun, T., Liu, Z., Kou, J., Liu, N., and Zhang, S., 2013. Mechanism of Sodium Sulfate in Promoting Selective Reduction of Nickel Laterite Ore during Reduction Roasting Process.International Journal of Mineral Processing, vol. 123, 32-38.

Li, G., Shi, T., Rao, M., Jiang, T., and Zhang, Y., 2012. Beneficiation of Nickeliferrous Laterite by Reduction Roasting in The Presence of Sodium Sulfate. Minerals Engineering, vol. 32, 19-26.

Li, G., Luo, J., Peng, Z., Zhang, Y., Rao, M., Jiang, T., 2015. Effect of Quarternary Basicity on Melting Behaviour and Ferronickel Particles Growth of Saprolitic Laterite Ores in Krupp Renn Process.ISIJ International, 55, 1828-1833.

Maksum, A., Husein, M. K. E., Permana, S., Rustandi, A., Soedarsono, J. W., 2018. A Preliminary Study on The Reduction of Limonite Ore by Using Rice Husk as a Reducing Agent. IOP Conf. Series and Engineering, 316, 012050.

Nurjaman, F., Rahmahwaty, A., Karimy, M. F., Hastriana, N., Shofi, A., Herlina, U., Suharno, B., Ferdian, D. 2019. The role of sodium-based additives on reduction of nickel laterite ore. IOP Conf. Series: Materials Science and Engineering 478 
(2019) $012001 \quad$ DOI:10.1088/1757899X/478/1/012001.

Oxley, A., Smith, M. E., Caceres, O. 2015. Why heap leach nickel laterite? Minerals Engineering, 88: 53-60.

Oxley, A., Barcza, N., 2013. Hydro-Pyro Integration in The Processing of Nickel Laterites. Minerals Engineering, 54, December, 2-13.

Pan, J., Zheng, G., Zhu, D., Zhou, X., 2013. Utilization of Nickel Slag using Selective Reduction by Magnetic Separation.Trans. Nonferrous. Met. Soc. China, 23, 3421-3427.

Petrus, H. T. B. M., Putera, A. D. P., Sugiarto, E., Perdana, I., Warmada, I. W., Nurjaman, F., Astuti, W., Mursito, A. T. 2019. Kinetics on Roasting Reduction of Limonitic Laterite Ore using Coconut-Charcoal and Anthracite Reductants. Minerals Engineering, 132, 126133.

Rao, M., Li, G., Jiang, T., Lio, J., Zhang, Y., and Fan, X., 2013. Carbothermic Reduction of Nickeliferous laterite Ores for Nickel Pig Iron Production in China: A Review. JOM, Vol. 60, No. 11, 1573-1583.

Rao, M., Li, G., Zhang, X., Luo, J., Peng, Z., and Jiang, T., 2016. Reductive Roasting of Nickel Laterite Ore with Sodium Sulphate for Fe-Ni Production, Part I: Reduction/Sulfidation Characteristics.Separation Science and Technology, vol. 51, 1408-1420.

Setiawan, I., Harjanto, S., Rustandi, A., and Subagja, R., 2014. Reducibility of Low Nickel Lateritic Ores with Presence of Calcium Sulfate. International Journal of Engineering and Technology, vol. 14, 56-66.

Setiawan, I., Triana, T., Febriana, E., Firdiyono, F. 2020. Carbothermic Selective Reduction of Laterite Nickel Ore by Addition of Sulfur and Sodium Hydroxide to Produce Ferronickel. Proceedings of the 3rd International Seminar on Metallurgy and Materials, AIP Conf. Proc. 2232, 060006-1 - 060006-9.

Shen, Y., Chong, J., Huang, Z., Tian, J., Zhang, W., Tang, X., Ding, W., and Du, X. 2019. Viscosity and structure of a $\mathrm{CaO}-\mathrm{SiO}_{2}-\mathrm{FeO}-$ $\mathrm{MgO}$ system during a modified process from nickel slag by $\mathrm{CaO}$. Materials, 12(2562):116. DOI: $10.3390 / \mathrm{ma} 12162562$.

Shofi, A., Rahmahwati, A., Nurjaman, F., Suharno, B., 2019. Effect of Reduction
Temperature and Sodium Based Additives on Nickel Up-Grading Process of Laterite Ores. IOP Conf. Ser.: Mater. Sci. Eng., 541, 012002

Solihin, 2015. Synthesis of Nickel Containing Pig Iron (NCPI) by using Limonite Type of Lateritic Ore from South East Sulawesi. Ris. Geo. Tam, Vol. 25, No. 1, 31-36.

Suharno, B., Ilman, N. P., Shofi, A., Ferdian, D., Nurjaman, F., 2019. Study of Low Grade Nickel Laterite Processing using Palm Shell Charcoal as Reductant. In. Proc. of Quality in Research Conference, 22-24 July 2019, Padang, Indonesia.

Tian, H., Pan, J., Zhu, D., Yang, C., Guo, Z., Xue, Y. 2020. Improved beneficiation of nickel and iron from a low-grade saprolite laterite by addition of limonitic laterite ore and $\mathrm{CaCO}_{3}$. Jounal of Materials Research and Technology, 9(2): 2578-2589.

Valix, M. and Cheung, W.H. 2002. Study of Phase Transformation of Laterite Ores at High Temperature. Minerals Engineering, 15, p. 607-612.

Warner, A. E. M., Díaz, C. M., Dalvi, A. D., Mackey, P. J., and Tarasov, A. V., 2006. JOM World Nonferrous Smelter Survey, Part III: Nickel: Laterite. JOM, 1-20.

Wills, B. A., and Napier-Munn, T., 2006. Wills' Mineral Processing Technology: An Introduction to the Practical Aspects of Ore Treatment and Mineral Recovery, 7th ed. Burlington, MA: Butterworth-Heinemann.

Zhu, D. Q., Chul, Y., Vining, K., Hapugoda, S., Douglas, J.,Pan, J.,\& Zheng, G. L., 2012. Upgrading Low Nickel Content Laterite Ores using Selective Reduction Followed by Magnetic Separation. International Journal of Mineral Processing, vol. 106-109, 1-7.

Zhu, D., Zhou, X., Luo, Y., Pan, J., Bai, B., 2016. Reduction Smelting Low Ferronickel from Pre-concentrated Nickel Iron Ore of Nickel Laterite", High Temp. Mater. Proc., 35 (10), 1031-1036.

Zhu, D., Pan, L., Guo, Z., Pan, J., Zhang, F. 2019. Utilization of limonitic nickel laterite to produce ferronickel concentrate by the selective reduction-magnetic separation process. Advanced Powder Technology, 30(2): 451-460. 